\title{
Possible Role of Selenium Nano-particles on Gentamicin-Induced Toxicity in Rat Testis:Morphological and Morphometric study
}

\author{
Original \\ Article \\ Amany Elsayed Mohammed Moussa Hamoud \\ Anatomy Department, Faculty of Medicine, Cairo University, Egypt
}

\begin{abstract}
Background: Gentamicin $(\mathrm{GM})$ is abroad spectrum antibiotic that used worldwide. Exact mechanism of its testicular toxicity is still unknown. The present study aimed at studying the possible protective role of selenium nano-particles (SeNPs) on histological, biochemical, and morphometric changes in rat testis.

Aim of Study: The current study was designed to elucidate the possible role of SeNPs on GM induced toxicity in rat testis. Materials and Methods: Twenty adult albino rats were divided into four groups, control, sham control, GM group, GM+ SeNPs group. The body weight (BW), testis weight, epididymis weight, seminal vesicle weight, prostate weight and serum testosterone level were determined. Testis sections were subjected to histological, morphometric, biochemical and statistical studies

Results: GM induced significant (sig) reduction in weight of testes, accessory sex organs, sperm count, motility and testosterone level. The drug also caused sig decrease in the activity of testicular catalase (CAT) and reduced glutathione (GSH) content, and sig increase in malondialdehyde (MDA) and $\mathrm{H} 2 \mathrm{O} 2$ levels. Sig increase in basement membrane (BM) thickness, area \% of caspase 3 immunoexpression (IE) and in Ki67 count were recorded. Injection of SeNPs improved sig the previously mentioned changes.

Conclusion: GM induced morphological, morphometric and biochemical changes on reproductive organs particularly testis of adult male rats. SeNPs administration with GM ameliorated these adverse effects that might be due to its antioxidant activity.
\end{abstract}

Received: 24 February 2019, Accepted: 01 May 2019

Key Words: Antioxidant, gentamicin, nanoparticle, selenium, testis.

Corresponding Author: Amany Elsayed Mohammed Moussa Hamoud, MD, Anatomy Department, Faculty of Medicine, Cairo University, Egypt, Cairo, Egypt, Tel.: +20 1020364428, E-mail: dramanyhamoud@gmail.com

ISSN: 1110-0559, Vol. 42, No. 4

\section{INTRODUCTION}

Antibiotics such as GM, neomycin, streptomycin and ofloxacin are used frequently by urologists, andrologist and in vitro fertilization infection treatment or when high concentration of leukocytes is present in the semen of these patients ${ }^{[1]}$. GM is an aminoglycoside broad spectrum antibiotic that has been approved in more than 100 countries worldwide. It is used especially against Gramnegative bacteria and streptococcus aureus ${ }^{[2]}$.

Nephrotoxicity, ototoxicity are a well-known adverse drawbacks of GM, although the exact mechanism assumed in that toxicity is not fully understood, but oxidative stress and reactive oxygen species (ROS) generation might be involved in the pathogenesis of toxicity ${ }^{[3]}$. The spermatozoa membrane is full of polyunsaturated fat, which make it susceptible to oxidative stress induced damage ${ }^{[4]}$.

Selenium (Se), due to its toxicity it was ignored as a therapeutic agent. Se is an essential trace element, which is very important antioxidant to human health and its deficiency might cause serious health effects ${ }^{[5]}$. It was proved that Se deficiency might affect the mitochondria in goat spermatozoa as it has a protective effect on mitochondria membrane integrity ${ }^{[6]}$.

The physicochemical properties of nanoparticles, such as size, surface charge, and hydrophobicity, affect their mucosal absorption characteristics as smaller particles showed higher cellular uptake ${ }^{[7]}$. SeNPs has a very wide range in biomedical applications as a nutritional and health improving supplements ${ }^{[8]}$. SeNPs possesses a better antioxidant ability than other chemical forms of selenium with reducing the risk of selenium toxicity ${ }^{[9]}$.

Previously, it was assumed that SeNPs were useful to prevent cisplatin (CIS)-induced gonadotoxicity ${ }^{[10]}$. As treatment with SeNPs significantly improved the serum testosterone, sperm quality and reduced CIS-induced free radical toxic stress and spermatic DNA damage in male rats.

The aim of the present study was to elucidate the possible role of SeNPs on GM induced toxicity in rat testis. 


\section{MATERIALS AND METHODS}

\section{Materials}

\section{Chemicals}

GM manufactured by Memphis Co. for Pharm. and Chem. Ind. (MEMCO), Egypt; under authority of ScheringPlough Corporation, U.S.A, Cairo, Egypt. In the form of ampoules of $2 \mathrm{ml} 40 \mathrm{mg} / \mathrm{mL}$ of gentamicin sulphate.

SeNps (40-45 $\mathrm{nm}$ particle size) were obtained from the Nano-Tech Egypt for Photo-Electronic, 6 October, Al Giza Egypt, as a sterilized solution, dispersed in phosphatebuffered saline (PBS) and ready for use. Transmission electron microscopy (TEM) was used for characterization of nanoparticles shape and size, on JEOL JEM-2100 high resolution microscope at an accelerating voltage of $200 \mathrm{kV}$. (Figure 1).

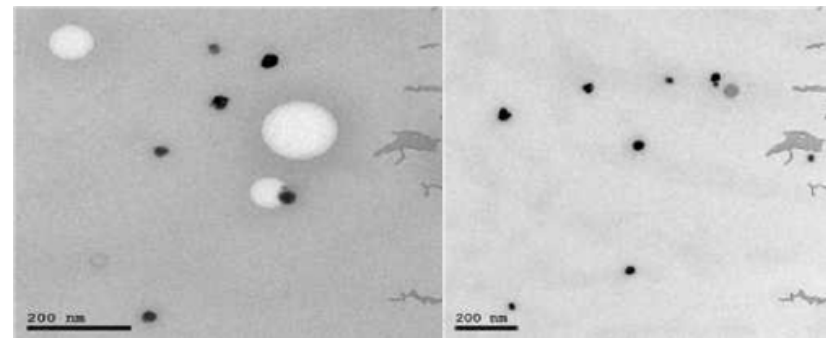

Fig. 1: Shows the TEM images of Nano selenium.

\section{Animals}

The current study was carried out on 20 adult albino rats, 3-5 months old weighing $(180-220 \mathrm{~g})$. The rats were obtained from Animal House of Kasr-Alainy, Faculty of Medicine, Cairo University. Rats were housed for one week for environmental adaptation under standard laboratory conditions at 22-24 C with 12 hours light/dark cycle. They were fed on a constant adequate nutrition diet and allowed free access to drinking water ad libitum. The experimental work was conducted in accordance with the guidelines of the Committee of Laboratory Animals at Kasr-Alainy.

\section{Rats were divided into four groups as follow}

\section{Control group: consist of five rats received nothing.}

Sham control group: consist of five rats received SeNPs $0.5 \mathrm{mg} / \mathrm{kg}$ intraperitoneal (IP) for 6 successive days ${ }^{[11]}$.

GM-treated group: consist of five rats received GM $100 \mathrm{mg} / \mathrm{kg}$ IP for 6 successive days ${ }^{[2]}$.

$\mathrm{GM}+\mathrm{SeNPs}$ group: consist of five rats received both gentamicin and selenium.

SeNPs will be administered IP to rats $1 \mathrm{hr}$ after the GM treatment with same dose and duration mentioned above. All rats were sacrificed by Cervical dislocation after light ether anathesia ${ }^{[12]}$.

\section{Methods}

- Determination of the body weight (BW) of all rats in different groups.

- Before sacrifice, blood was collected from the tail veins of animals belonging to each group using capillary tubes for assessment of serum testosterone.

- Median abdominal incision was performed and organs were disected. Testes, epididymis, seminal vesicle and prostate were removed and weighed. The absolute organ weights and relative weights (organ weight /body weight X100) were measured for each rat and recorded. Both testes were fixed in $10 \%$ formol saline for 24 hours.

- Epididymal sperm motility percentage: abnormalities and Live- sperm Percentages: A drop of freshly undiluted semen solution from the cauda epididymis was mixed with one drop of physiological saline on the slide. The progressively motile sperm percentage was evaluated microscopically under high power lens ${ }^{[13]}$.

- Epididymal Sperm Count: epididymal spermatozoa were counted by a modified method ${ }^{[14]}$. The count was done through mincing of epididymis in 5 $\mathrm{ml}$ saline, then in a rocker for $10 \mathrm{~min}$ at room temperature. About $10 \mu 1$ of semen was transferred to a chamber of Neubaur haemocytometer (Depth $0.1 \mathrm{~mm}$; LABART, Germany) then put for $5 \mathrm{~min}$ before counting with light microscope at high power lens.

- Quantitative polymerase chain reaction (qPCR): formalin-fixed paraffin-embedded (FFPE) testes specimens by qPCR were performed ${ }^{[16]}$. Reverse Transcription is carried out with the SuperScript First-Strand Synthesis System for reverse transcriptase (RT)-PCR ${ }^{[17]}$. The following ribonucleic acid (RNA)/primer (Table 1) mixture was prepared in each tube: $5 \mu \mathrm{g}$ total RNA and 3 $\mu 1$ random hexamers. The specimens were put at $65^{\circ} \mathrm{C}$ for $5 \mathrm{~min}$ and ice for only one min. Reaction master mixture was prepared for each reaction then added to the RNA/primer mixture and mixed briefly, after that placed at room temperature two minutes. $1 \mu \mathrm{l}$ (50 units) of SuperScript II RT was added to each tube, mixed and incubated at $25^{\circ} \mathrm{C}$ for $10 \mathrm{~min}$. The tubes were incubated at $42^{\circ} \mathrm{C}$ for $50 \mathrm{~min}$, heat inactivated at $70^{\circ} \mathrm{C}$ for $15 \mathrm{~min}$, and then chilled on ice. $1 \mu \mathrm{l}$ RNAase $\mathrm{H}$ was added and incubated at $37^{\circ} \mathrm{C}$ for $20 \mathrm{~min}$. The 1st strand complementary deoxyribonucleic acid (cDNA) was stored at $-20^{\circ} \mathrm{C}$ until use for real-time PCR. The primer concentrations were normalized, genespecific and reverse primer pair were mixed. A 
copy of the setup file was saved and all PCR cycles were deleted [used for later dissociation curve analysis]. $50^{\circ} \mathrm{C} 2 \mathrm{~min}, 1$ cycle, $95^{\circ} \mathrm{C} 10 \mathrm{~min}, 1$ cycle, $95{ }^{\circ} \mathrm{C} 15$ seconds $->60{ }^{\circ} \mathrm{C} 30$ seconds $->72$ ${ }^{\circ} \mathrm{C} 30$ seconds, 40 cycles and $72^{\circ} \mathrm{C} 10 \mathrm{~min}, 1$ cycle. A real-time PCR reaction mixture can be either 50 $\mu \mathrm{l}$ or $25 \mu \mathrm{l}$. After PCR is finished, the tubes were removed from the machine.

Table 1: The primer sequence of the studied Steroidogenic acute regulatory gene (STAR) and 3 Hydroxy steroid dehydrogenase (3HSD) gene

\begin{tabular}{ll}
\hline & Primer sequence \\
\hline \multirow{2}{*}{ STAR } & Forward: 5'-GGGCATACTCAACAACCAG-3' \\
& Reverse: 5'-ACCTCCAGTCGGAACACC-3' \\
\multirow{2}{*}{3 HSD } & Forward :5-TGTGCCAGCCTTCATCTAC-3' \\
& Reverse :5'-CTTCTCGGCCATCCTTTT-3' \\
\multirow{2}{*}{ Beta actin } & Forward primer:5'--GGTCGGTGTGAACGGATTTGG -3 \\
& Reverse primer:5'-ATGTAGGCCATGAGGTCCACC-3 \\
\hline
\end{tabular}

\section{- Oxidative and antioxidative parameters}

1. Measurement of Malanodialdehyde (MDA) concentration, Glutathione (GSH) concentration and Catalase (CAT) activity: half the specimens were kept in the deep freezer for homogenization. $1 \mathrm{gm}$ of muscle was homogenized in $10 \mathrm{ml}$ normal saline by using homogenizer (Ortoalresa, Spain). Then centrifuged at $1000 \mathrm{X}$ g for about 10 minutes. It was collected in and kept in the deep freezer (at $20^{\circ} \mathrm{C}$ ) reduced $\mathrm{GSH}, \mathrm{CAT}$ and $\mathrm{MDA}^{[18]}$.

2. Estimation of Hydrogen Peroxide $\left(\mathrm{H}_{2} \mathrm{O}_{2}\right)$ levels were measured by Pick $^{[19]}$. $100 \mathrm{uL}$ of tissue homogenate was prepared in Tris- $\mathrm{HCl}$ buffer (20 mM, pH7.4) and $100 \mathrm{uL}$ of assay solution (containing $0.2 \mathrm{~mL}$ phenol red, $0.2 \mathrm{~g} / \mathrm{L}$ and $0.2 \mathrm{~mL}$ of horse radish peroxidase, $20 \mathrm{U} / \mathrm{mL}$ in potassium phosphate buffer, $0.05 \mathrm{M}$, pH 7.0, and $9.6 \mathrm{~mL}$ of $0.9 \% \mathrm{NaCl}$ ) was taken and reaction was started by the addition of $10 \mathrm{uL}$ of $1.0 \mathrm{~N} \mathrm{NaOH}$. Absorbance was recorded at $600 \mathrm{~nm}$ in a microplate using ELISA reader. Hydrogen peroxide standard curve was plotted by taking different concentrations of $\mathrm{H} 2 \mathrm{O} 2$ for assay of $\mathrm{H}$, ranging from 20 to 100 $\mathrm{mmol}$ in a total volume of $100 \mathrm{uL}$ and processed in the same way. Results are expressed as $\mathrm{mmol}_{2} \mathrm{O}_{2}$ formed $/ \mathrm{mL}$ homogenate.

- Paraffin blocks were prepared and 5um thick sections were subjected to the following studies

1. Histological and histochemical study: Hematoxylin and eosin (H and E) stain ${ }^{[20]}$. PAS stain ${ }^{[21]}$.

2. Immunohistochemical study: Caspase3 immunostaining $^{[22]}$, the marker for apoptosis. $7 \mathrm{ml}$ of rabbit polyclonal Ab (RB-1197-R7) (Lab Vision Corporation, USA) was prediluted ready to use solution stored at $2-8^{\circ} \mathrm{C}$. The +ve tissue control was a specimen of human tonsil. Caspase $3+v e$ cells showed cytoplasmic reaction.
Ki 67 immunostaining ${ }^{[23]}$ polyclonal rabbit antirat 1ry $\mathrm{Ab}$ (MKI67/NB110-897171) $\mathrm{mg} / \mathrm{ml}$, nuclear reaction, proliferation marker, dilution 1:100-1:500. +ve control tonsil, -ve control ommit application of 1ry Ab, apply for 60 minutes.

- Morphometric study: Using Leica Qwin 500 LTD (Cambridge, UK) computer assisted image analysis system, thickness of the basement membrane (BM) in PAS stained sections and count of +ve nuclei in $\mathrm{Ki} 67$ were done in immuno-stained sections using interactive measurements menu. The area \% of caspase 3 immuno expression (IE) and optical density of caspase 3 IE were estimated using binary mode. The measurements were done in 10 high power fields.

- Statistical study: Quantitative data were summarized as means and standard deviations and compared using one-way analysis-of-variance (ANOVA). Any significant ANOVA was followed by post hoc Tukey test to detect which pairs of groups caused the significant difference. $P$-values $<0.05$ were considered statistically $\operatorname{sig}^{[24]}$. Calculations were made on Statistical Package of Social Science (SPSS) software version 16.

\section{RESULTS}

Mean $B W$, testes and reproductive organs weight

No clinical signs of toxicity were noticed neither in GM group nor in GM+SeNPs groups. However, a sig decrease was found in BW, absolute and relative weights of testes, seminal vesicles, prostates and epididymis in GM group when compared to the other groups. In contrast, the previously mentioned weights of reproductive organs were recorded to be significantly increased in the GM + SeNPs treated group when compared with GM group. (Table 2, Histogram 1)

\section{Hormonal, sperm count and motility changes}

Serum testosterone, sperm count and motility were sig decreased in both GM-treated and combined GM+SeNPs groups compared with control (Table 3, Histogram 1).

\section{Oxidative and antioxidative parameter changes}

Measurement of the serum contents GSH, CAT were sig decreased in GM group compared with other three groups. While, MDA and $\mathrm{H}_{2} \mathrm{O}_{2}$ were sig increased in $\mathrm{GM}$ than other groups. Star and 3HSD genes in GM group, SeNPs groups were decreased sig compared with the control group. On the other hand, sig increase was detected in SeNPs+GM group compared to GM group (Table 3, Histogram 1).

\section{Histological and histochemical changes}

Histological examination showed normal appearance of seminiferous tubule arrangement and cellular lining (spermatogonia, spermatocytes and spermatids) with minimal connective tissue in between in both control and Sham groups (Figures 2a,b,c). While in GM group, wide spacing between the tubules appeared and some tubules revealed minimal spermatogenic cell lining 
(Figure 2d). High magnification demonstrated lining spermatogonia only (Figure 2e) and other tubules with obvious vacuoles among the lining cells (Figures $3 \mathrm{~g}, 3 \mathrm{~h})$. In $\mathrm{Gm}+\mathrm{SeNPs}$, the tubules were apparently normal with congested vessels in between (Figure 2f). Restoration of normal spermatogenic lining with residual minimal vacuolation and congested vessels were seen (Figures 3g).

Sections in the testis of rats stained by PAS showed multiple seminiferous tubules with apparently normal $\mathrm{BM}$ with normal thickness in control (Figures $4 \mathrm{a}, 4 \mathrm{~b}$ ). In GM group thickened BM of some tubules, showed wavy $\mathrm{BM}$, folded $\mathrm{BM}$ and thinning of $\mathrm{BM}$ with focal disruption (Figures $4 \mathrm{c}, 4 \mathrm{~d}, 4 \mathrm{e}, 4 \mathrm{f}$ ). In $\mathrm{GM}+\mathrm{SeNPs}$ group some tubules showed thinning of the BM (Figure $5 \mathrm{~g}$ ) and others revealed partially thickened BM (Figure 5h).

\section{Immunohistochemical changes}

Weak positive reaction of caspase 3 IE was detected in few interstitial cell in control group (Figure 6a), with cytoplasmic reaction of Leydig cells (Figure 6b). In GM group increased density of IE in the interstitial cells of some areas (Figure 6c), +ve IE in some cells lining some tubules (Figure 6d) with increased density and distribution of IE in other areas (Figure 6e). In GM+SeNPs group minimal increase in density and IE were found in some interstitial cells (Figure 6f). Regarding Ki67+ve nuclear IE was detected in few interstitial cells in control group (Figure 7a). While in GM group +ve nuclear IE in some interstitial and spermatogenic cells were observed (Fig ure 7b), in GM+SeNPs group +ve nuclear IE in was evident in multiple interstitial and spermatogenic cells (Figure 7c).

\section{Morphometric changes}

The mean BM thickness in PAS stained sections, mean area $\%$ of caspase 3 IE and optical density of caspase 3 IE detected indicated a sig increase in the GM group compared to other groups and in Se-treated group compared to the control groups. Regarding count of Ki67 +ve nuclei a sig increase in GM group was evident as compared to control groups and sig increase in GM+SeNPs group as compared to other groups (Table 4, Histogram 2).

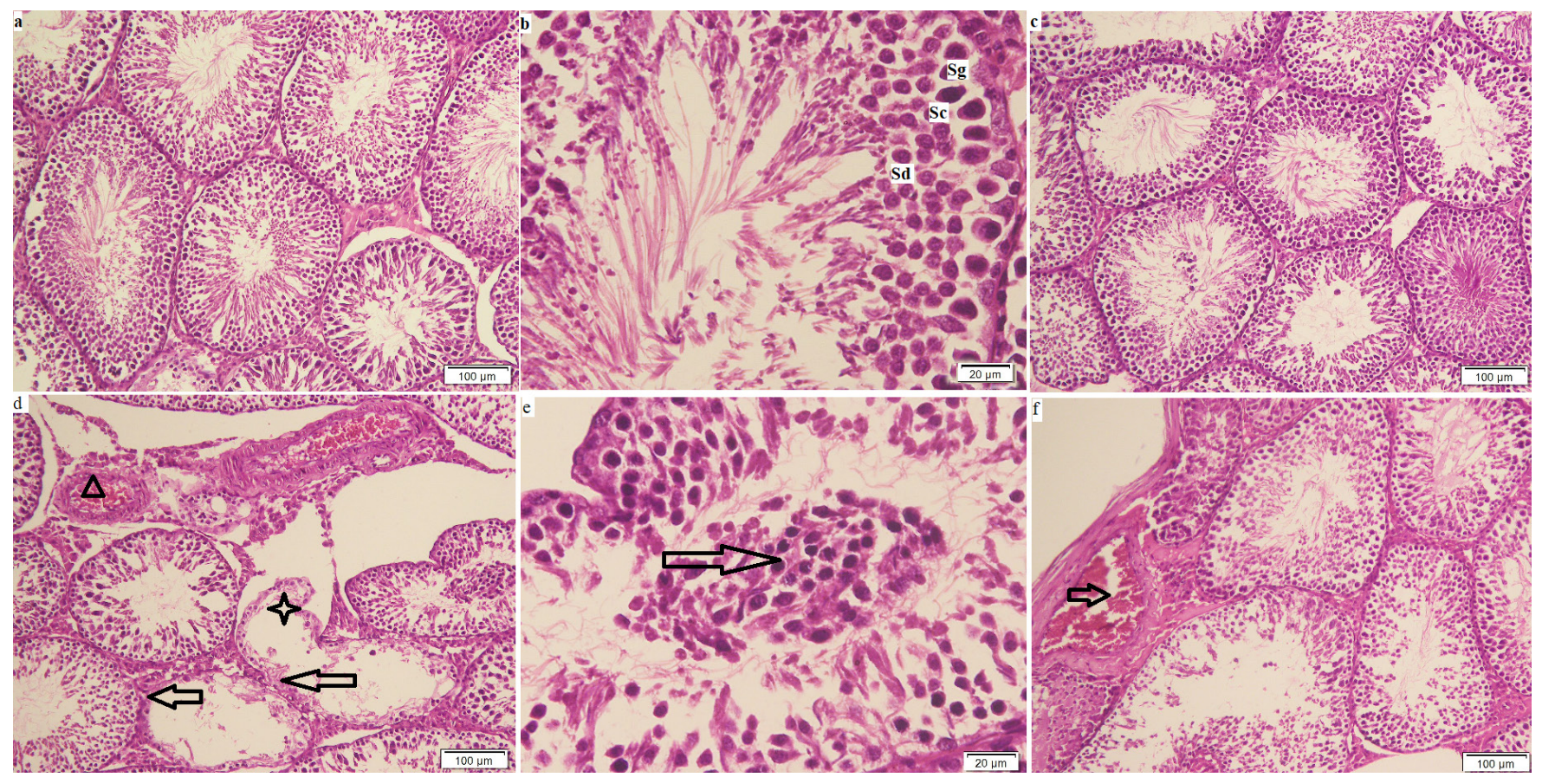

Fig. 2: Sections in the testis of rats ( $\mathrm{H}$ and $\mathrm{E})$ representing: a) and c) control and sham control apparently normal seminiferous tubules with minimal connective tissue in between ( $\mathrm{H}$ and Ex100).b) higher magnification of control group showing apparently normal spermatogonia (Sg), 1ry spermatocytes (Sc) and spermatids (Sd) (H and Ex400). d) GM group showing a distorted tubule with reduced lining (star), two tubules with reduced lining (arrows) and two congested vessels (triangle) (H and Ex100). e) GM group showing dislodged spermatogenic cells inside the lumen of a seminiferous tubule (arrow) (H and Ex400). f) $\mathrm{GM}+\mathrm{SeNPs}$ showing apparently normal tubules and a congested vessel (arrow) (H and Ex100). 


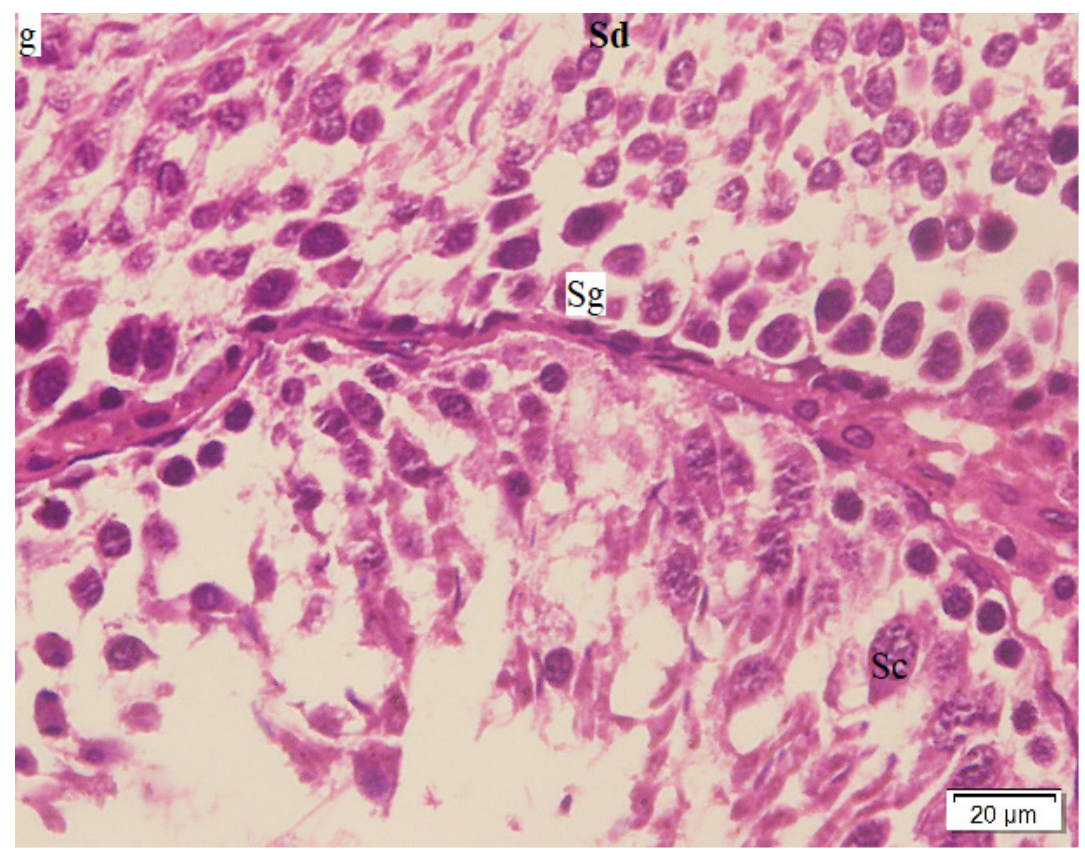

Fig. 3g: Sections in the testis of rats (H and Ex400) representing: g) GM+SeNPs showing restoration of normal spermatogenic lining spermatogonia (Sg), 1ry spermatocytes $(\mathrm{Sc})$ and spermatids $(\mathrm{Sd})$.

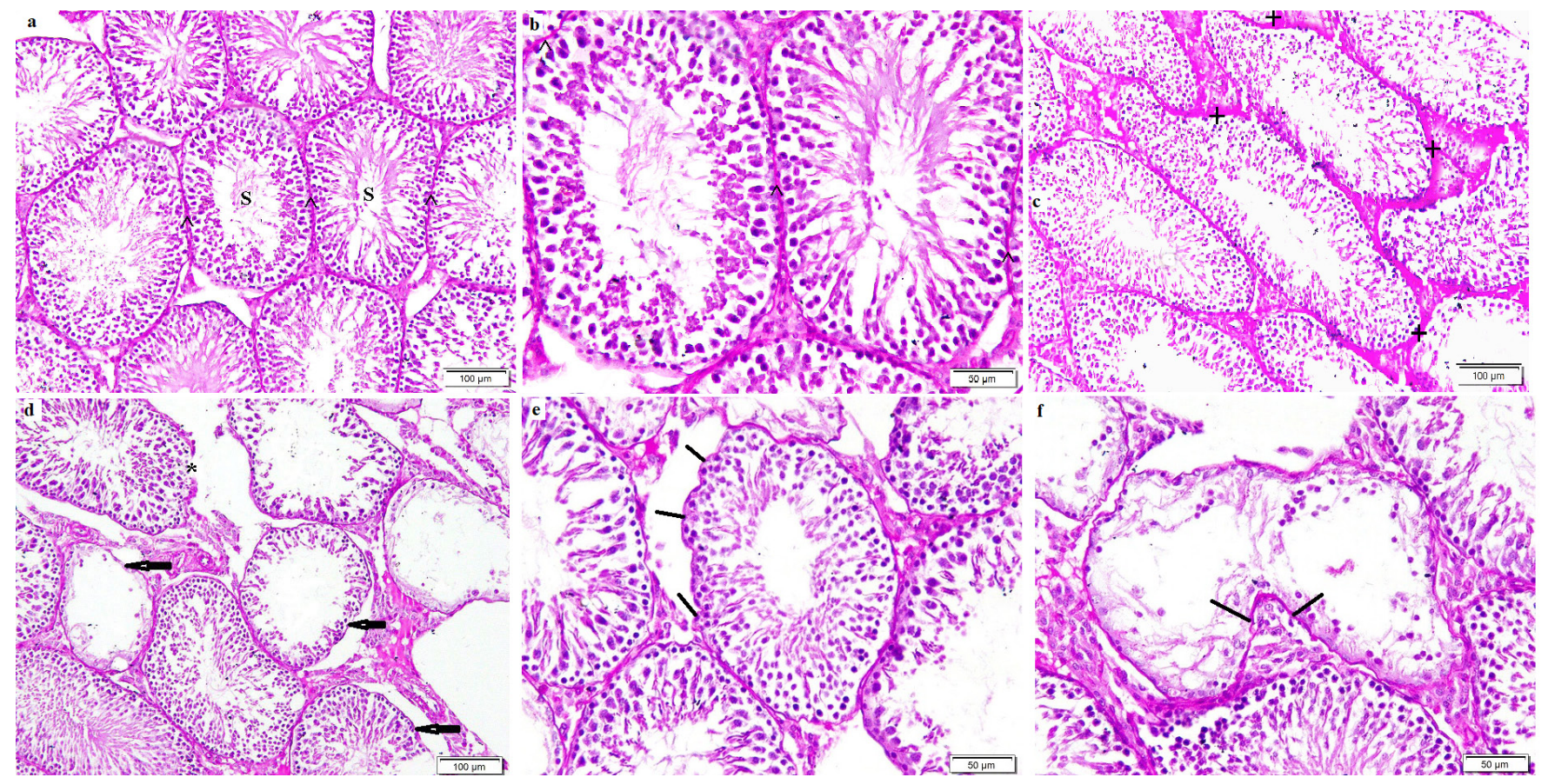

Fig. 4: Sections in the testis of rats (PAS) representing: a) control rat showing multiple seminiferous tubules (S) with apparently normal basement membrane $\left.(\mathrm{BM})\left({ }^{\wedge}\right)(\mathrm{PASx} 100) . \mathrm{b}\right)$ control rat showing normal thickness of the BM $\left({ }^{\wedge}\right)(\mathrm{PASx} 200)$. c) GM group showing thickened BM of some tubule $(+)(\mathrm{PASx} 100)$. d)GM group showing thinned BM (arrows)of some tubules and focal disruption (star) of BM of a tubule (PASx100).e) and f) GM group showing a wavy BM (lines) of a tubule and a folded BM (lines) of another respectively (PASx200). 


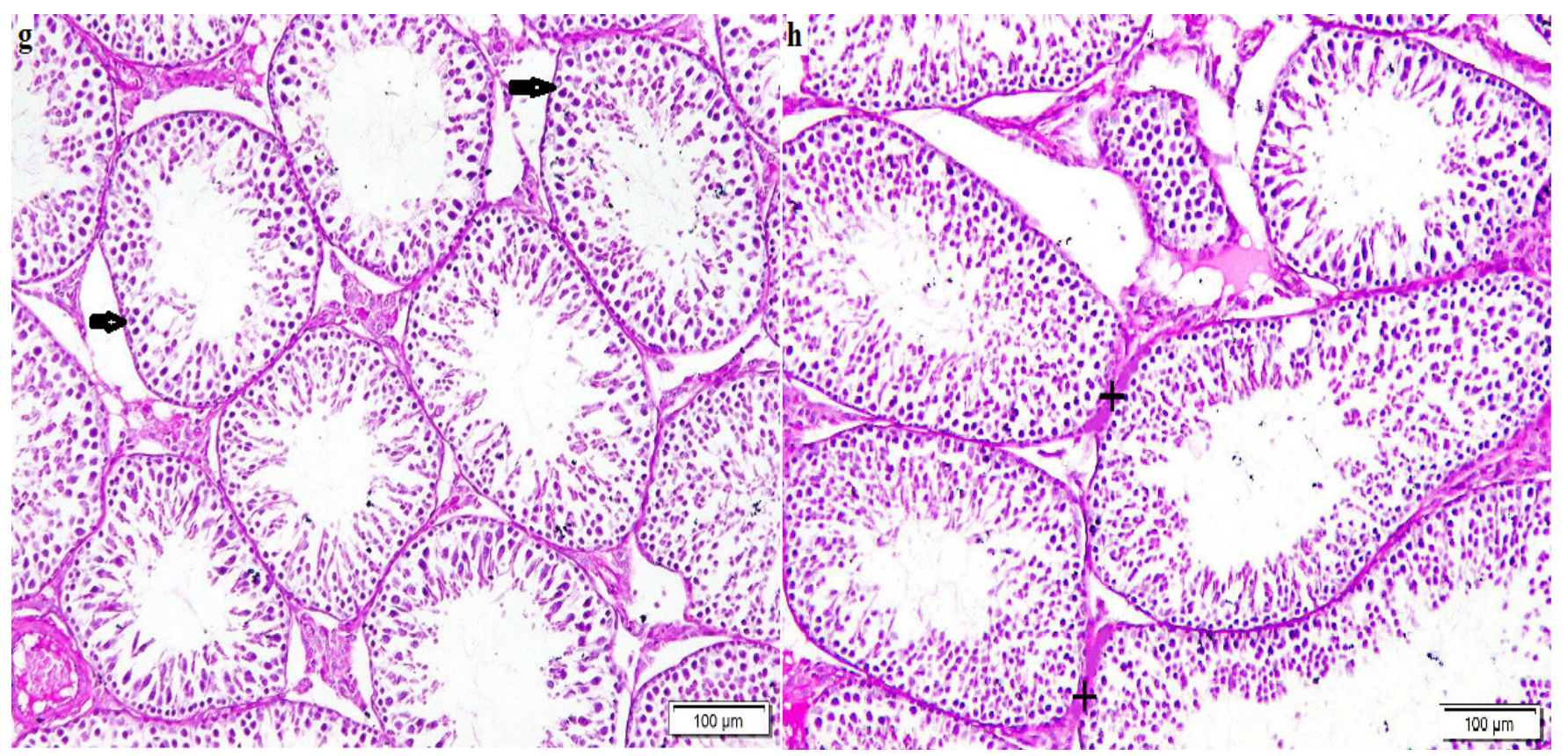

Fig. 5: Sections in the testis of rats (PASx100) representing: g) GM+SeNPs group showing some tubules with thin BM (arrows). h)GM+SENPs group showing some tubules with partially thickened $\mathrm{BM}(+)$.

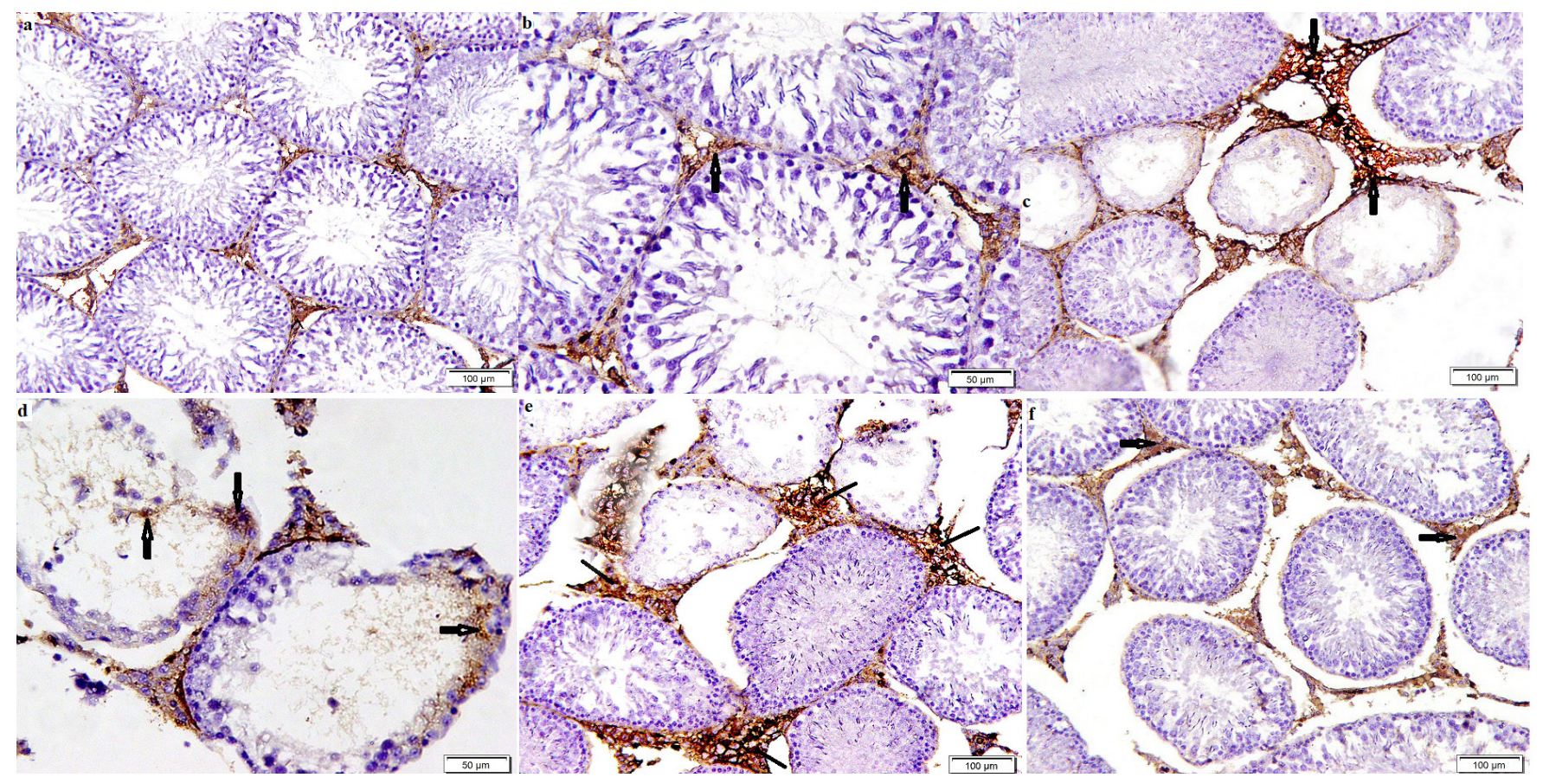

Fig.6: Sections in the testis of rats (Caspase3 immunostaining) representing: a) control rat showing weak +ve caspase3(IE)(arrow head) in few interstitial cells (caspase3 immunostaining x100).b)control rat showing cytoplasmic reaction of Leydig cells(arrows)(caspase3 immunostaining x200).c)GM group showing increased density of IE in multiple interstitial cells(arrows) (caspase3 immunostaining x100). d)GM group showing +ve IE in the cells lining two tubules (arrow)(caspase3 immunostaining x200).e)GM group showing increased density and distribution of IE(lines)(caspase3 immunostaining x100). f)GM+SeNPs group showing minimal increase in IE and density reaction (arrows) in some interstitial cells(caspase 3 immunostaining $\mathrm{x} 100$ ). 


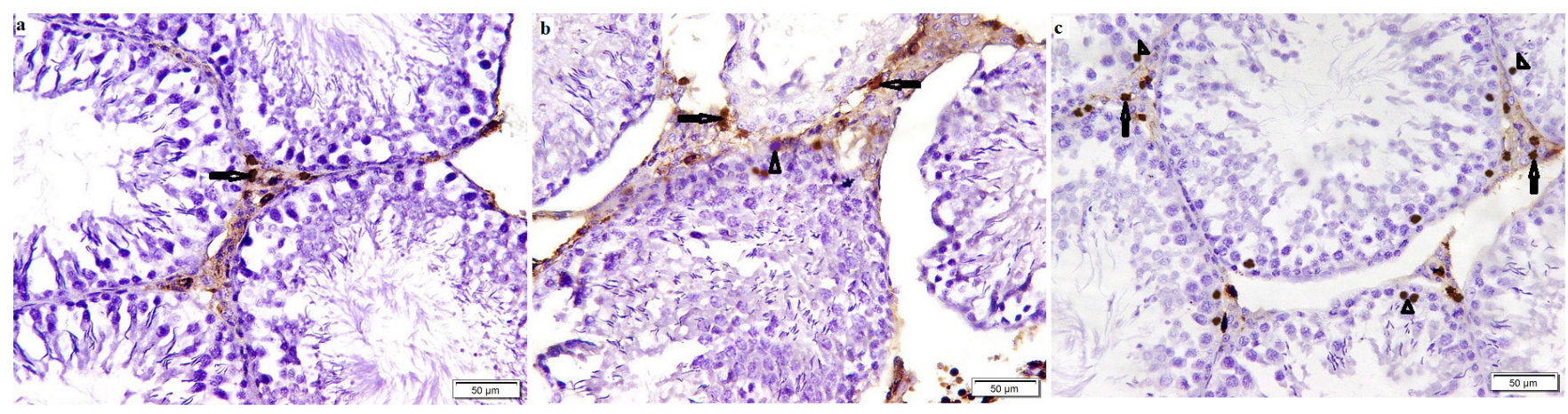

Fig 7: Sections in the testis of rats (Ki67 immunostaining, $x$ 200) representing: a)control rat showing +ve nuclear IE in few interstitial cells (arrow).b) GM group showing +ve nuclear IE in some interstitial cells (arrows) and spermatogenic cells (triangle).c) GM+SeNPs group showing +ve nuclear IE in multiple interstitial cells (arrows) and spermatogenic cells (triangles).

Table 2: Absolute and relative reproductive organ weights in different groups.

\begin{tabular}{|c|c|c|c|c|c|}
\hline & Control & Sham control & GM group & $\mathrm{Gm}+\mathrm{SeNPs}$ & \multirow{2}{*}{$P$ value } \\
\hline & Mean \pm SD & Mean \pm SD & Mean \pm SD & Mean \pm SD & \\
\hline $\mathrm{BW}$ & $157.2 \pm 8.17$ & $157.4 \pm 5.98$ & $137.2 * \pm 3.11$ & $158.2 \pm 6.76$ & $<0.001$ \\
\hline Testes weight & $1.1 \pm 0.07$ & $1.1 \pm 0.13$ & $0.7 * \pm 0.03$ & $1.0 \pm 0.03$ & $<0.001$ \\
\hline Epididymis weigh & $1.1 \pm 0.06$ & $1.1 \pm 0.11$ & $0.8^{*} \pm 0.04$ & $1.0 \pm 0.06$ & $<0.001$ \\
\hline Prostate weight & $0.3 \pm 0.02$ & $0.3 \pm 0.02$ & $0.2 * \pm 0.01$ & $0.3 \pm 0.02$ & $<0.001$ \\
\hline Seminalvesicle weight & $0.7 \pm 0.02$ & $0.7 \pm 0.03$ & $0.3^{*} \pm 0.02$ & $0.5 * \pm 0.08$ & $<0.001$ \\
\hline RelativeTestes weight & $0.7 \pm 0.02$ & $0.7 \pm 0.07$ & $0.5^{*} \pm 0.03$ & $0.6^{*} \pm 0.04$ & $<0.001$ \\
\hline Relative epididymis weight & $0.7 \pm 0.07$ & $0.7 \pm 0.07$ & $0.6^{*} \pm 0.04$ & $0.7 \pm 0.06$ & $\leq 0.001$ \\
\hline relative prostate weight & $0.2 \pm 0.01$ & $0.2 \pm 0.02$ & $0.1^{*} \pm 0.01$ & $0.2 \pm 0.02$ & $<0.001$ \\
\hline relative seminal vesicle weight & $0.4 \pm 0.02$ & $0.4 \pm 0.02$ & $0.2 * \pm 0.02$ & $0.3^{*} \pm 0.04$ & $<0.001$ \\
\hline
\end{tabular}

* statistically sig different than other three groups.

Table 3: Showing oxidative and antioxidative parameter and gene expression changes.

\begin{tabular}{|c|c|c|c|c|c|}
\hline & Control & Sham control & GM group & $\mathrm{SeNPs}+\mathrm{GM}$ & \multirow{2}{*}{$P$ value } \\
\hline & Mean \pm SD & Mean \pm SD & Mean \pm SD & Mean \pm SD & \\
\hline Sperm count $X 10^{6}$ & $33.2 \pm 0.08$ & $33.1 \pm 0.10$ & $21.7 * \pm 0.07$ & $28.4 * \pm 0.05$ & $<0.001$ \\
\hline Sperm motility $\%$ & $45.1 \pm 0.11$ & $45.3 \pm 0.11$ & $17.7 * \pm 0.09$ & $29.1 * \pm 0.11$ & $<0.001$ \\
\hline Serum testosterone (unit) & $1.5 \pm 0.11$ & $1.4 \pm 0.08$ & $0.8^{*} \pm 0.02$ & $1.2 * \pm 0.08$ & $<0.001$ \\
\hline GSH (unit) & $59.6 \pm 4.98$ & $56.0 \pm 0.16$ & $22.6^{*} \pm 0.10$ & $49.2 * \pm 0.13$ & $<0.001$ \\
\hline CAT (unit) & $121.7 \pm 0.13$ & $121.6 \pm 0.10$ & $76.2 * \pm 0.13$ & $118.0 * \pm 0.18$ & $<0.001$ \\
\hline $\mathrm{H}_{2} \mathrm{O}_{2}$ (unit) & $3.2 \pm 0.09$ & $3.0 \pm 0.18$ & $12.8^{*} \pm 0.10$ & $7.4 * \pm 0.11$ & $<0.001$ \\
\hline MDA (unit) & $10.0 \pm 0.13$ & $10.0 \pm 0.21$ & $43.6 * \pm 0.23$ & $21.5^{*} \pm 0.11$ & $<0.001$ \\
\hline STAR (unit) & $1.1 \pm 0.08$ & $1.1 \pm 0.11$ & $0.2 * \pm 0.01$ & $0.7 * \pm 0.01$ & $<0.001$ \\
\hline HSD3 (unit) & $1.1 \pm 0.08$ & $1.2 \pm 0.10$ & $0.2 * \pm 0.01$ & $0.7 * \pm 0.01$ & $<0.001$ \\
\hline
\end{tabular}

* statistically sig different than other three groups.

Table 4: Mean thickness of BM, area\% of caspase3 IE, optical density of caspase 3 IE and count of Ki67 +ve nuclei.

\begin{tabular}{|c|c|c|c|c|}
\hline Group & Thickness BM & Area\% & Optical density & Count of Ki67 +ve \\
\hline Control & $0.15 \pm 0.02$ & $2.00 \pm 0.04$ & $0.20 \pm 0.02$ & $2.80 \pm 0.53$ \\
\hline Control-Sham & $0.16 \pm 0.01$ & $2.03 \pm 0.05$ & $0.25 \pm 0.01$ & $2.90 \pm 0.50$ \\
\hline GM & $0.89 \pm 0.08 *$ & $9.43 \pm 0.21^{*}$ & $0.74 \pm 0.11^{*}$ & $5.80 \pm 1.09^{\wedge}$ \\
\hline SeNPs & $0.29 \pm 0.03^{\wedge}$ & $4.68 \pm 0.16^{\wedge}$ & $0.43 \pm 0.12^{\wedge}$ & $11.50 \pm 2.49 *$ \\
\hline
\end{tabular}

Sig $P \leq 0.05 . \quad$ - sig compared to control groups . - * sig compared to the other groups. 


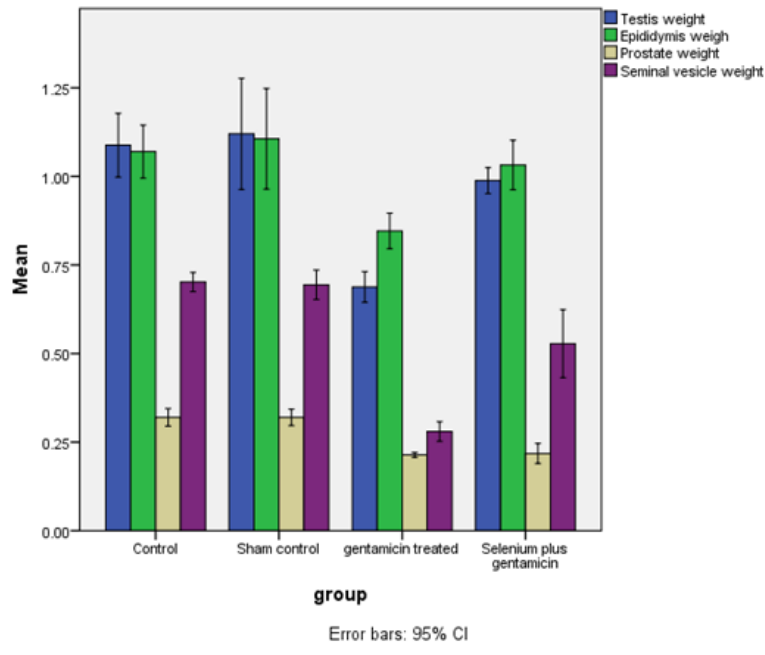

Histogram 1a: Mean organs weight

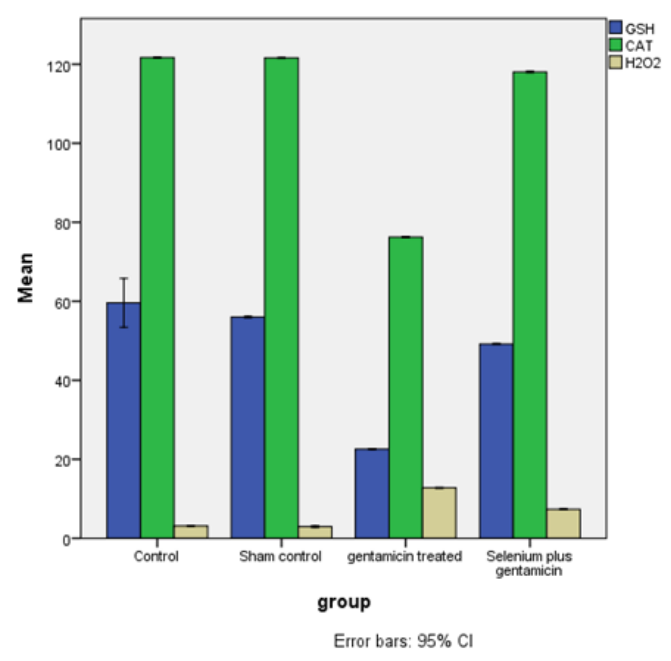

Histogram 1b: Mean GSH,CAT, $\mathrm{H}_{2} \mathrm{O}_{2}$

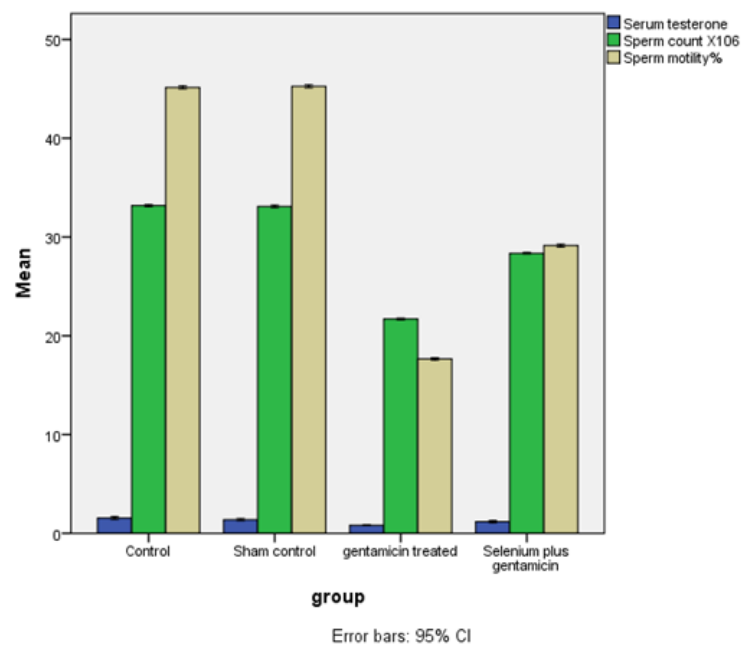

Histogram 1c: Mean serum testosterone sperm count and motility

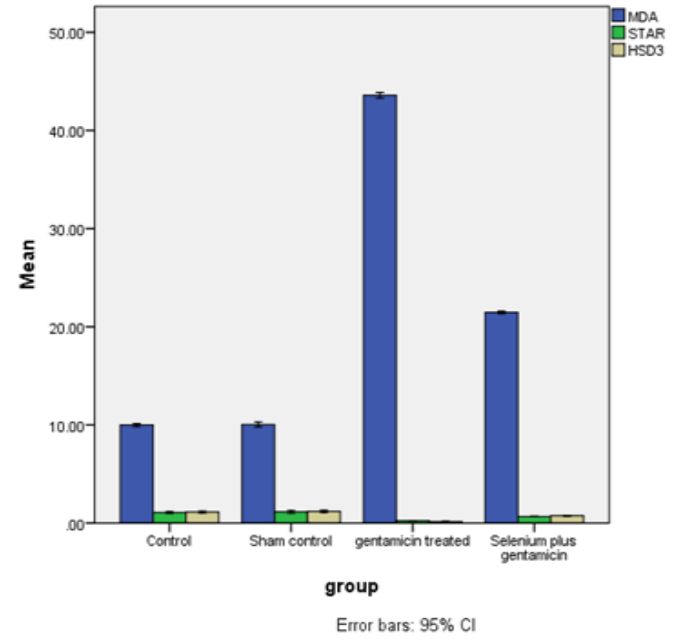

Histogram 1d: Mean of MDA, STAR and and HSD genes

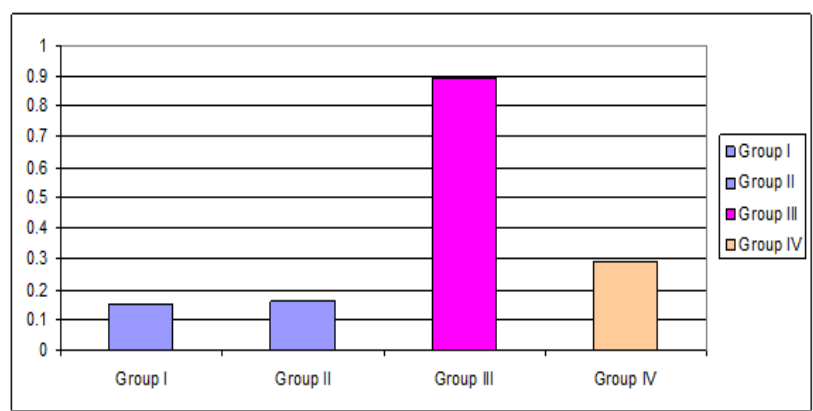

Histogram 2a: Thickness of BM

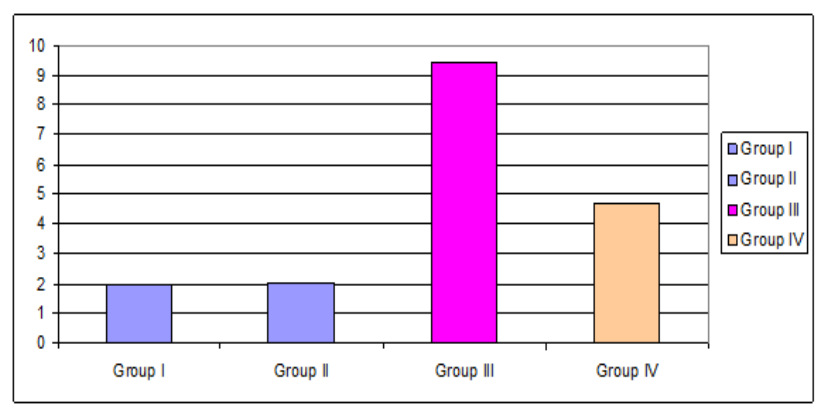

Histogram 2b: Area\% of caspase3 IE

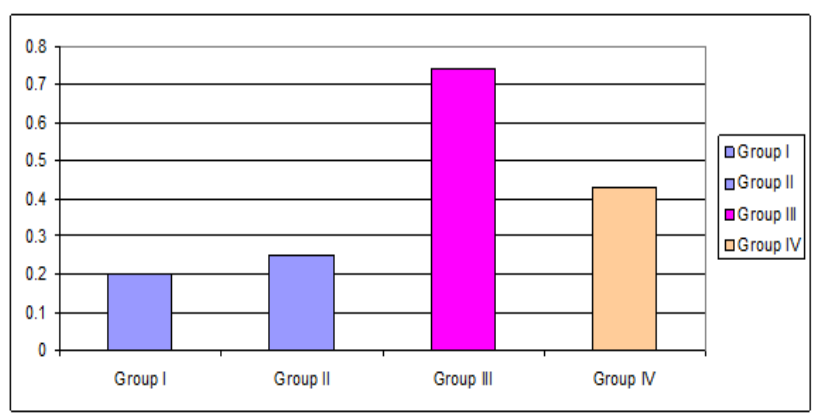

Histogram 2c: Optical density of caspase3 IE 


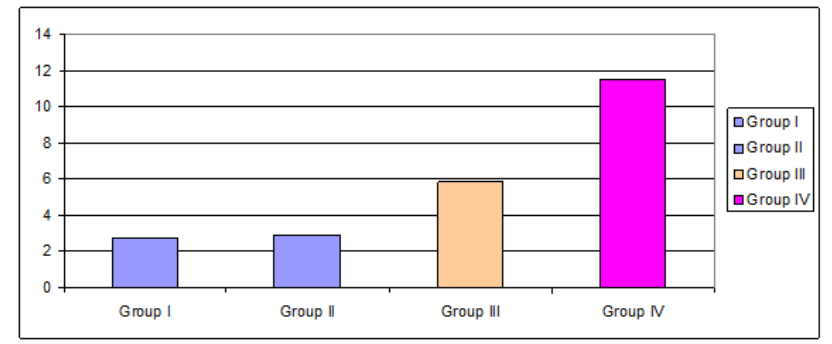

Histogram 2d: Count of Ki67 +ve nuclei

\section{DISCUSSION}

The present study investigated the biochemical, histological, histochemical, immunohistochemical and morphometric changes that may develop in the rat testis exposed to GM and the possible protective role of SeNPs. GM as abroad spectrum antibiotic used worldwide mainly by urologist but it affects male fertility that's why it raises the concern about studying the different protective modalities.

In the present study, GM influence testes and accessory sex organs weight as well sperm count and motility which showed sig reduction in GM group as compared to all other groups. This weight reduction might be due to decrease in the spermatogenic cell mass as well decreased seminiferous tubule size due to atrophy as a result of cell death. However, concomitant treatment with SeNPs showed slight improvement in the previous finding, that might be due to shorter duration of treatment. In agreement with these results, weight reduction was referred to direct cytotoxic effect of GM on accessory sex organs and their secretions ${ }^{[2]}$. Same findings were reported by researcher who studied the effect of different aminoglycoside antibiotics such as gentamicin, neomycin and streptomycin on sperm count and motility ${ }^{[25]}$. He added that GM sig decreased the epididymis, testes and seminal vesicles weights as well the sperm count and motility as a result of Leydig and spermatogenic cells destruction.

Oxidative stress is one of the most important causes of induction of different organs toxicity. In the current work, testicular homogenate content of GSH, CAT was sig decreased in GM group. While, MDA and $\mathrm{H}_{2} \mathrm{O}_{2}$ were sig increased than other groups which indicated the role of oxidative stress on testicular toxicity, therefore expecting these changes to be ameliorated by the antioxidant treatment as in the present work. That is in support, with a recent study which proved that free radicals have the potentiality to oxidize proteins, lipids and DNA ${ }^{[26]}$. The authors added that the enzyme glutathione peroxidase $(\mathrm{GPx})$ is a selenium dependent enzyme and its main function is $\mathrm{H}_{2} \mathrm{O}_{2}$ removal and it prevents formation of highly reactive hydroxyl $(\mathrm{OH})$ radical.

It was explained that the spermatogenesis and Leydig cell steroidogenesis are vulnerable to oxidative stress due to very high rate of cell division and mitochondrial oxygen consumption in testicular tissue ${ }^{[27]}$. In addition, it was stated that the testes contain many antioxidant enzymes and free radical scavengers to ensure that both spermatogenic and steroidogenic functions of this organ not to be affected. Use of vitamin E supplement and selenium considerably improved sperm motility and viability. GPx use GSH as a source of electrons to reduce $\mathrm{H}_{2} \mathrm{O}_{2}$ to water. $\mathrm{GPx}$ was found in the mitochondria, nucleus and acrosomal domain of differentiating spermatozoa. Therefore animals fed on a selenium deficient diet exhibit a significant reduction of testicular GPx activity and an accompanying loss of germ cells from the germinal epithelium of the testes ${ }^{[28]}$.

Serum testosterone reduction found in the present study might be due to disturbed oxidant antioxidant state ${ }^{[29]}$. This finding can relate decreased sperm count to gentamicin induced testosterone level reduction, being essential for normal spermatogenesis ${ }^{[30]}$. Previously, it was suggested that necrosis of Leydig cell or diminished stimulation of the cells by interstitial cells stimulating hormone is the reason for testosterone reduction ${ }^{[31]}$.

In the present work, STAR and 3HSD genes in GM group were sig decreased as compared with the control group, both are prerequisites for testosterone production in Leydig cells of the mammalian testis. STAR protein regulates the transport of cholesterol to the inner mitochondrial membrane which is the rate-limiting step in steroid biosynthesis in various tissues ${ }^{[15]}$. It is primarily expressed in Leydig cells in the testes, which make it essential for testosterone production and male fertility.

Histological and histochemical examination showed various morphological alterations in the seminiferous tubule, characterized by degeneration, reduced cell lining, decrease of spermatogenic cells numbers and BM thickening that might be as a direct effect of GM. Testicular testosterone concentration reduction might be the key factor in these degenerative changes ${ }^{[30]}$. Another explanation for gentamicin induced testicular degeneration was assumed through the generation ROS as superoxide, $\mathrm{H}_{2} \mathrm{O}_{2}$ which is frequently used to produce oxidative and necrotic damages ${ }^{[25]}$.

Caspases are involved in proteins degradation and known to be participated in cleaving neighboring amino acids, once caspases are activated, there seems to be a sequence to cell death ${ }^{[32]}$. The caspase-3 activates cytoplasmic endonucleases that degrade the nuclear materials and proteins then followed by DNA fragmentation ${ }^{[33]}$. Area $\%$ of caspase 3 that have been measured in the current work revealed sig increase in GM group compared to the control which was obvious in interstitial cells than in the lining of seminiferous tubules. It has been implicated that caspase-3 activation is the principal factor in apoptotic cell death ${ }^{[34]}$. Treatment with SeNPs sig reduced the area $\%$ of caspase 3 IE that might be due to its antioxidant activity.

Ki67 is an antigen that is found during different cell cycle phases of proliferating cells and absent in cells that arrested in the G0 phase ${ }^{[35]}$. GM effect on testicular cells proliferation was done and assessed by means of Ki67 immunohistochemistry and highest count was measured in 
SeNPs group indicating cellular proliferation and repair. It was postulated that the positive expression level of Ki-67 is a good response to spermatogenesis dysfunction ${ }^{[35]}$.

\section{CONCLUSION}

It can be concluded that GM induced morphological, morphometric and biochemical changes indicative of degeneration on the reproductive organs of the adult male rat particularly the testis. However, SeNPs elicited a sig protective role against GM-induced toxicity due to its antioxidant activity.

So the present study recommends that SeNPSs can be used concomitantly with the prescription of GM to reduce its adverse effect, and it can be proposed to be used for longer periods of time than that used in the present study to ensure more remarkable effect.

\section{CONFLICTS OF INTEREST}

There are no conflicts of interest.

\section{LIST OF ABBREVIATION}

GM: gentamicin.

SeNPs: selenium nanoparticles.

BW: Body weight.

Sig: significant.

CAT: catalase.

GSH: glutathione.

MDA: malonaldehyde.

BM: basement membrane.

IE: immunoexpression.

Se:selenium.

PBS: phosphate buffer saline.

TEM: transmission electron microscope.

IP: intraperitoneal.

qPCR: quanitative polymerase chain reaction.

FFPE: formalin fixed paraffin embedded.

+ve: Positive.

Ab: Antibody.

STAR:steriodgenic acute regulatory gene.

3HSD:3 hydroxy steroid dehydrogenase.

$\mathrm{H} 2 \mathrm{O} 2$ : hydrogen peroxide.

ANOVA: Analysis of variance.

C: Centigrade.

HandE: Haematoxylin and eosin.

PAS:Periodic acid Shiff.
SPSS: Statistical Package of Social Science.

$\mathrm{OH}$ : hydroxyl.

GPx: glutathione perioxidase.

\section{REFERENCES}

1. Khaki A, Khaki AA, Iraj S, Bazi P, Imani SAM, Kachabi H. Comparative study of aminoglycosides (gentamicin and streptomycin) and (fluoroquinolone ofloxacin) antibiotics on testis tissue in rats: light and transmission electron microscopic study. Pak J Med Sci 2009;25(4): 624-629.

2. Kim SH, Lee IC, Baek HS, Shin IS, Moon C, Kim SH, Yun WK, Nam KH, Kim HC, Kim JC. Melatonin prevents gentamicin-induced testicular toxicity and oxidative stress in rats. Andrologia 2014;46(9):1032-1040.

3. Hong SH, Park SK, Cho YS, Lee HS, Kim KR, Kim MG, Chung WH. Gentamicin induced nitric oxide-related oxidative damages on vestibular afferents in the guinea pig. Hear Res 2006; 211(12):46-53.

4. Kumar R, Gautam G, Gupta NP. Drug therapy for idiopathic male infertility: rationale versus evidence. J Urol 2006;176:1307-1312.

5. Tinggi U. Selenium: its role as antioxidant in human health. Environ Health Prev Med 2008; 13(2):102-108.

6. Shi LG, Yang RJ, Yue WB, Xun WJ, Zhang CX, Ren YS, Shi L, Lei FL. Effect of elemental nanoselenium on semen quality, glutathione peroxidase activity and testis ultrastructure in male Boer goats. Anim Reprod Sci 2010;118(2):248-254.

7. Petros R, DeSimone JM. Strategies in the design of nanoparticles for therapeutic applications. Nat Rev Drug Discov 2010; 9(8):615-627.

8. Qiu WY, Wang YY, Wang M, Yan JK. Colloids Surf B Biointerfaces Construction, stability and enhanced antioxidant activity of pectin-decorated selenium nanoparticles. 2018;170:692-700.Epub head of print.

9. Hosnedlova B, Kepinska M, Skalickova S, Fernandez C, Ruttkay-Nedecky B, Peng Q, Baron M, Melcova M, Opatrilova R, Zidkova J, Bjørklund $\mathrm{G}$, Sochor J, Kizek R .Nano-selenium and its nanomedicine applications: a critical review. Int $\mathrm{J}$ Nanomedicine 2018;13:2107-2128.

10. Rezvanfar MA, RezvanfarMA,ShahverdiAR,Ahm adiA, BaeeriM, Mohammadirad A, Abdollahi M. Protection of cisplatin-induced spermatotoxicity, DNA damage and chromatin abnormality by selenium nano-particles. Toxicol Appl Pharmacol 2013;266(3):356-365. 
11. Asri-Rezaei S, Nourian A, Shalizar-Jalali A, Najafi G, Nazarizadeh A, Koohestani M, Karimi A. Selenium supplementation in the form of selenium nanoparticles and selenite sodium improves mature male mice reproductive performances. Iran J Basic Med Sci 2018; 21(6):577-585.

12. Iranpour FG, Kheiri S. Coadministration of calcium chloride with lead acetate can improve motility of cauda epididymal spermatozoa in Swiss white mice. Int J Reprod BioMed 2016;14(2): 141-144.

13. Bearden H, Fuquay W J. Applied Animal Reproduction.1980 Reston Publishing Co., Inc. Reston, Virgini app: 158-160.

14. Yokoi K, Uthus E O, Nielsen F H. Nickel deficiency diminishes sperm quantity and movement in rats. Biol Trace Elem Res 2003; 93:141-154.

15. Zhang Y, Cui Y, Zhang X, Wang Y, Gao J, Yu T, Lv X, Pan C. Pig StAR: mRNA expression and alternative splicing in testis and Leydig cells and association analyses with testicular morphology traits. Theriogenology. 2018;118:46-56. Epub head of print.

16. Burckhardt MA1, Udhane SS1, Marti N1, Schnyder I1, Tapia C1, Nielsen JE1, Mullis PE1, Rajpert-De Meyts E1, Flück CE2. Human $3 \beta$-hydroxysteroid dehydrogenase deficiency seems to affect fertility but may not harbor a tumor risk: lesson from an experiment of nature. Eur $\mathrm{J}$ Endocrinol. 2015;173(5):1-12.

17. Pu T, Guo P, Qiu Y, Chen S, Yang L, Sun L, Ye $\mathrm{F}, \mathrm{Bu} \mathrm{H}$. Quantitative real-time polymerase chain reaction is an alternative method for the detection of HER-2 amplification in formalin-fixed paraffinembedded breast cancer samples. Int J Clin Exp Pathol 2015; 8(9): 10565-10574.

18. Brancaccio P, Lippi G, Maffulli N. Biochemical markers of muscular damage. Clin Chem Lab Med 2010; 48(6): 757-767.

19. Pick E. Microassay for superoxide and hydrogen peroxide production and nitroblue tetrazolium reduction using an enzyme immunoassay microplate reader. Methods Enzymol 1996; (132):407-421.

20. Kiernan JK. Histological and Histochemical methods. In: Theory and practice. 3rd ed, Arnold Publisher, London, New York and New Delhy 2001; 111-162.

21. Bancroft JD, Gamble M. Carbohydrates. In: Theory and practice of histological techniques, $6^{\text {th }}$. Elsevier Health Sciences, Churchill Livingstone, Edinburgh, London, Oxford, New York, Philadelphia, St Louis, Sydney and Toronto 2008; 161-186.
22. Sun W, Su Q, Cao X, Shang B, Chen A, Yin H, Liu B. High expression of polo-like kinase 1 is associated with early development of hepatocellular carcinoma. Int J Genomics. 2014;2014: 312130-312138.

23. Rostamzadeh, Ayoob and Ghadimi, Tayyeb and Allahveisi, Azra and Mohammadi, Mohsen and Rezaei, Shohreh and Rezaie, Mohammad. The expression of bax protein in the early stages of spinal cord injury in the sperm cells of rats. Polish Annals of Medicine 2018 ;25(2):196-202.

24. Emsley R, Dunn G, White I. Mediation and moderation of treatment effects in randomized controlled trials of complex interventions. Stat Methods Med Res 2010;19(3): 237-270.

25. Khaki A. Assessment on the adverse effects of Aminoglycosides and Flouroquinolone on sperm parameters and male reproductive tissue: A systematic review. Iran J Reprod Med 2015;13(3):125-134.

26. Chetankumar R, Acharya, Hetal N, Thakar , Vajpeyee S K .A study of oxidative stress in gentamicin induced nephrotoxicity and effect of antioxidant vitamin C in Wistar rats. NatI J Physiol Pharm Pharmacol 2013; 3(1)14-20.

27. Asadi N, Bahmani M, Kheradmand A, RafieianKopaei M. The Impact of Oxidative Stress on Testicular Function and the Role of Antioxidants in Improving it : A Review .JClinDign Res.2017;11(5):IE01-IE05.

28. González de Vega R, Fernández-Sánchez ML, Fernández JC, Álvarez Menéndez FV, SanzMedel A. Selenium levels and Glutathione peroxidase activity in the plasma of patients with type II diabetes mellitus. J Trace Elem Med Biol. 2016;37:44-49.

29. Adewoyin M, Ibrahim M, Roszaman R, Isa M, Alewi N, Rafa A, Anuar M. Male infertility:the effect of natural antioxidants and phytocompounds on seminal oxidative stress. Diseases 2017; 5: 1-26.

30. Mohamed SM, ElHawary NM, Mohamed SF, Hashim NI, Saleh SY, Bakeer MR and Sawiress FA. Effect of stem cell therapy on gentamicin induced testicular dysfunction in rats. J Health Med Informat 2017; 8:263.

31. Zhang Y, Cui Y, Zhang X, Wang Y, Gao J, Yu T, Lv X, Pan C. Pig StAR: mRNA expression and alternative splicing in testis and Leydig cells and association analyses with testicular morphology traits. Theriogenology. 2018;118:46-56. Epub head of print. 
32. Sakai W, Suqasawa K. FANCD2 is a target for caspase 3 during DNA damage-induced apoptosis. FEBS Let t. 2014;588:3778-3785.

33. MosadeghM, HasanzadehS, RaziM. Nicotineinduced damages in testicular tissue of rats; evidences for bcl-2, p53 and caspase-3expression. Iran JBasicMedSci.2017;20(2):199-208.

34. Miller I, Min M, Yang C, Tian C, Gookin S, Carter D, Spencer S L. Ki67 is a graded rather than a binary marker of proliferation versus quiescence. Cell reports 2018; 24 (5), 1105-1112.

35. Zhao WP, Wang HW, Liu J, Tan PP, Luo XL, Zhu SQ, Chen XL, Zhou BH. Positive PCNA and Ki67 Expression in the testis correlates with spermatogenesis dysfunction in fluoride-treated rats. Biol Trace Elem Res.2018;186 (2):489-497. Epub head of print. 


\title{
الملخص العربى
}

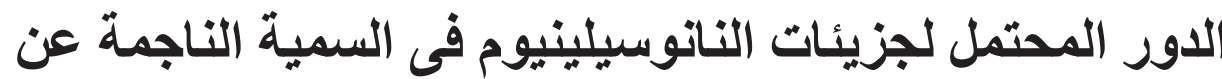 الجنتاميسين فى خصية الفئران: دراسة مورفولوجية ولئية وقياسية}

\author{
أماني السيا محمد موسي حمود
}

مدرس التشريح والأجنة كلية الطب- جامعة القاهرة

المقدمة: جنتاميسين هو مضاد حيوي يستخدم في جميع أنحاء العالم. الآلية الدقيقة لسمية الخصية الناتجة عنة لا تز ال غير معروفة. تهذف هذه الدراسة إلى دراسة الدور الوقائي المحتمل لجزيئات النانو سيلينيوم في التغيرات النسيجية الناتجة و الكيميائية الحيوية و القياسية في خصية الفئر ان نتيجة إستخدام الجنتاميسين. الهدف من الاراسة: صمدت الدراسة الحالية لتوضيح الدور المحتمل لجزيئات النانوسيلينيوم فى السمية الناجمة عن الجنتاميسين في خصية الفئران. المواد والطرق: تم تقسيم عشرون فأر ا من فئر ان الألبينو إلى أربع مجمو عات: مجمو عتين مر اقبة، مجمو عة الجنتاميسين ومجموعة الجنتاميسين مع النانوسيلينيوم. تم تحديد وزن الجسم، وزن الخصية، وزن البربخ، وزن الحويصلة المنوية، وزن البروستاتا ومستوى هرمون التستوستيرون. وفى نهاية التجربة تم أخذ عينات من الخصية وتم اعداد شرائح مجهرية وصبغها بالهيماتوكسلين و الإيوسين ومن ثم القياسات المورفومترية و الكيميائية الحيوية و الإحصائية. النتائج: الجنتاميسين يسبب انخفاض كبير في وزن الخصيتين والأعضاء الجنسية التابعة مثل البربخ، الحويصلة المنوية، البروستاتاو عدد وحركة الحيو انات المنوية، ومستوى هرمون التستوستيرون. تسبب الدواء أيضا فى انخفاض نسبة الجلوتاثيون ونشاط انزيمات الأكسدة وانخفاض مساحة ٪ من التعبير المناعي.عند حقن النانوسيلينيوم تم تحسين التغبير ات المذكورة سابقا. استتناج: أدت إضافة النانوسيلينيوم إلى تحسين الآثار الضارة الناتجة عن إستخدام الجنتاميسين في خصية الفئران و التي قد تكون بسبب نشاطها المضاد للأكسدة. 